\title{
HEMOPHILIA PATIENT WITH DIFFICULTY IN BLOOD PRESSURE CONTROL
}

\author{
Ugur Mehmet Can, ${ }^{1}$ Atabay Yusuf, ${ }^{2}$ Akar Harun ${ }^{2}$ \\ ${ }^{1}$ Izmir Bozyaka Education and Training Hospital, Department of Hematology, Turkey \\ ${ }^{2}$ Izmir Tepecik education and training hospital, Department of internal medicine, Turkey
}

Primljen/Received 30. 07. 2018. god.

Abstract: Hypertension prevalence is increasing in patients with hemophilia. Therefore it is an important complication of hemophilia. We aimed to present a 49-year-old male patient with hemophilia-A who presented with acute hemarthrosis and hypertensive attack. The patient was treated in our internal medicine clinic.

Key words: Hemophilia, hypertension.

\section{INTRODUCTION}

Comorbid conditions are more common in hemophilia patients since the life span in hemophilia patients is longer than those of previous years due to improvements in hemophilia care. One of the most common comorbid conditions seen in hemophilia patients is hypertension (1). We aimed to present a hemophilia patient who presented with acute hemarthrosis and hypertensive attack to our internal medicine clinic.

\section{CASE REPORT}

A 49-year-old male patient with hemophilia-A was admitted to the emergency room due to swelling in his right knee 2 days before. On physical examination, blood pressure (BP) was $220 / 110 \mathrm{mmHg}$, heart rate was $92 / \mathrm{min}$, swelling in the right knee was remarkable. Hemogram and routine biochemical parameters were normal except for prolonged activated prothrombin time $($ APTT $=115 \mathrm{sec})$. The recombinant factor eight present in the patient itself was given at a dose of 50 $\mathrm{IU} / \mathrm{kg}$. The 30th minute control APTT value was determined to be 38 seconds. He was admitted to our Internal medicine Clinic because of the failure of controling $\mathrm{BP}$ in the emergency department and the diagnosis of hemarthrosis and hypertensive attack. After the administration of perindopril-indapamide $5 / 1.25 \mathrm{mg}$ combi-
Prihvaćen/Accepted 03. 09. 2018. god.

nation and bisoprolol $5 \mathrm{mg}$ in treatment, BP gradually reached the target values. Because of admission to the hospital with hypertensive attack, we planned the test in order to determine the cause of hypertensive attack. Left ventricular concentric hypertrophy was detected on echocardiography. No pathological findings were observed in abdominal ultrasonography and renal artery doppler ultrasonography. Rheumatological parameters, urine metanephrine and normetanephrine values were in normal range. The patient was evaluated as an essential hypertension. The discharge of the patient was considered due to the regression of hemarthrosis and adequate blood pressure control. It was discharged with a combination of perindopril / indapamide and bisoprolol. The patient was directed to a center where factor 8 and inhibitor tests could be performed.

\section{DISCUSSION AND CONCLUSION}

Prevalence of hypertension is increasing in patients with hemophilia (2). Hypertension is thought to be more common in hemophilia patients than nonhemophiliacs $(3,4)$. The cause of increased prevalence of hypertension in cases with hemophilia is unknown. Sedentary lifestyle due to increased bleeding risk is one of the hypotheses (2). In patients with increased risk of bleeding such as mild and severe hemophilia, hypertension may be affected by the obligatory sedantery lifestyle due to the risk of bleeding. Interaction of hemostatic factors with the vascular wall or reduction in hemostasis is thought to be the effect on vascular tone or endothelial relaxation $(5,6)$. There are also studies showing that hypertension triggers bleeding episodes. Our patient was admitted together with attacks of bleeding and hypertension. Elderly hemophilia patients should be closely monitored to avoid comorbidities and bleeding episodes. Antihypertensive therapy sho- 
uld be considered concurrently with factor 8 replacement in the management of patients with a risk of hypertensive attack and hemophilia. Since pieces of information on the prevalence and severity of hypertension is limited during hemophilia, it is important to investigate the frequency and pathogenesis of hypertension in hemophiliacs.

\section{DECLARATION OF INTEREST}

The autors declare that there are no conflicts of interests.

\section{Licensing}

This work is licensed under a Creative Commons Attribution 4.0 International (CC BY 4.0) License.

\title{
Sažetak
}

\section{PACIJENT SA HEMOFILIJOM SA POTEŠKOĆAMA U KONTROLI KRVNOG PRITISKA}

\author{
Ugur Mehmet Can, ${ }^{1}$ Atabay Yusuf, ${ }^{2}$ Akar Harun ${ }^{2}$ \\ ${ }^{1}$ Izmir Bozyaka Education and Training Hospital, Department of Hematology, Turkey \\ ${ }^{2}$ Izmir Tepecik education and training hospital, Department of internal medicine, Turkey
}

Prevalenca hipertenzije kod pacijenata sa hemofilijom je u porastu. Dakle, može se reći da je hipertenzija ozbiljna komplikacija hemofilije. Cilj našeg rada bio je da predstavimo 49-godišnjeg muškog pacijenta koji

\section{REFERENCES}

1. Miesbach W, Reitter-Pfoertner SE, Klamroth R, Langer F, Wolf HH, Tiede A et al. Co-morbidities and bleeding in elderly patients with haemophilia-A survey of the German, Austrian and Swiss Society of Thrombosis and Haemostasis Research (GTH). Haemophilia. 2017; 23(5): 721-7.

2. von Drygalski A, Kolaitis NA, Bettencourt R, Bergstrom J, Kruse-Jarres R, Quon DV et al. Prevalence and risk factors for hypertension in hemophilia. Hypertension. 2013; 62(1): 209-15.

\author{
Correspondence to/Autor za korespondenciju \\ Mehmet Can Ugur \\ Izmir Bozyaka Education and Training Hospital \\ Department of Hematology \\ Karabaglar/Izmir/TURKEY \\ Phone: +90 5058861126 \\ email: med.can@hotmail.com
}

boluje od hemofilije A, kod kojeg se javila akutna hemartroza i napadi hipertenzivne krize. Pacijent je lečen u našoj Klinici za internu medicinu.

Ključne reči: hemofilija, hipertenzija.

3. Ljung RC. Intracranial haemorrhage in haemophilia A and B. Br J Haematol. 2008; 140(4): 378-84.

4. Nilsson IM, Berntorp E, Löfqvist T, Pettersson H. Twenty-five years' experience of prophylactic treatment in severe haemophilia A and B. J Intern Med. 1992; 232(1): 25-32.

5. Keller SA, Moore CC, Clemens MG, McKillop IH, Huynh T. Activated protein $\mathrm{C}$ restores hepatic microcirculation during sepsis by modulating vasoregulator expression. Shock. 2011; 36(4): 361-9.

6. Ma yszko J, Tymcio J. Thrombin activatable fibrinolysis inhibitor and other hemostatic parameters in patients with essential arterial hypertension. Pol Arch Med Wewn. 2008; 118(1-2): 36-41. 